\title{
THE MANAGEMENT OF CARDIAC ARREST IN A GENERAL HOSPITAL
}

T. A. Don Michael, M.B., M.R.C.P.(Lond.), M.R.C.P.(Edin.)

Registrar to the Cardiac Dept., The London Hospital, E. I

(Formerly Registrar, St. Stephen's Hospital, London, S.W'.10)

D. J. E. TAYLOR, M.B., M.R.C.P.(Lond.)

Registrar, St. Stephen's Hospital, London, S.W.10

A. W. WaRLTIER, M.A., M.B., B.Chir., L.R.C.P., M.R.C.S. Medical Officer-in-Charge, Casualty Dept., St. Stephen's Hospital

CARDIAC arrest may be presumed to have occurred in the presence of a clinical picture of pulselessness, apnoa and unconsciousness, in a patient who had not been expected to die (Safar, 1961). This definition takes into account the importance of making an early diagnosis, where specialized equipment is not at hand.

Until recently, the emergency could be treated adequately only when it occurred in situations which enabled swift thoracotomy and intubation to be performed. The advent of closed-chest resuscitation techniques, however, has extended the scope of treatment outside the aseptic confines of the operating theatre and focused attention on methods of dealing with the problem wherever it may occur. With the application of these techniques there has grown the realization that cardiac arrest is by no means an uncommon event. In a general hospital such as St. Stephen's, with a large turnover and a busy casualty department, we have found the emergency to occur frequently enough to warrant a critical consideration of the methods used, and the formulation of a definite plan of action. The difficulties imposed by the limitations of time, and the lack of specialized equipment had to be taken into account in drawing up such a scheme. Despite this however, we have found cardiac resuscitation to be a practical proposition, and one capable of saving life.

The history of cardiac resuscitation is replete with examples of attempts to restore one or other of the vital functions of the circulation and respiration. Thus the prophet Elisha is said to have revived the Shunammite boy:

' he put his mouth upon his mouth ... and stretched himself upon the child and the flesh of the child waxed warm '. (Kings II, Chap. 4, 32-37.)

Andreas Vesalius and John Hunter attempted resuscitation by intubation and positive pressure ventilation (Willius and Dry, 1948; Hunter, 1776). William Harvey was the first to record the restoration of heart action as observed, experimentally.
He touched ths motionless heart of a pigeon witio his finger:

'... wetted with saliva and warm . . . and it started to pulsate ... recalled as it were from death to life ... (Clendening, 1942).

It was Moritz Schiff (1896) who showed tha? massage of the heart could restore its action and maintain the circulation.

The first successful human resuscitation was reported in I90I (Igelsrud), and this was closelp followed by another in 1902 (Starling and Larg) These occurred during surgery and anæstheșap respectively, and massage was given by intrathoracic routc. It was in 1906 that closed chest massage was first used (Crile and Walley 1906). These workers produced cardiac arrest in dogs by artificial means, and showed that a com气 bination of thoracic compression, artificial ventila $\mathbb{D}$ tion, intravenous fluids and adrenaline could restore circulation. They made the point tha $\bar{B}$ thoracic compression, given rhythmically, needecF to be vigorously performed for success. The application of closed-chest external massage ing human beings however, was delayed by a further. half century, until it was mooted as the procedure of choice (Kouwenhoven, Jude and Knickerbocker 1960). Previous to this, cardiac massage had necessarily entailed opening the chest. These workers were able to show, in all but one of $1 \mathrm{ig}$ cases, that external massage was capable of pro $\frac{D}{8}$ ducing a palpable pulse. They obtained systolie. blood pressures of over $200 \mathrm{~mm}$. $\mathrm{Hg}$ althoughs diastolic pressures tended to be of the order of 30 to $50 \mathrm{~mm}$. $\mathrm{Hg}$. A direct record of bloo\$ pressure was made with a catheter in the descend $\omega$ ing aorta during cardiac massage. From the very outset, pressures of $80 \mathrm{~mm}$. $\mathrm{Hg}$ were obtainec (Gurewich, 196r). The inference that an easil felt pulse is a satisfactory criterion of perfusion has been criticized (Nixon, 196r; Weale and Rothwell-Jackson, 1962). However, there seem\$ to be no. reason to doubt this, according to the्ष 
clinical experience of those who have used external massage. Blood pressures and actual flows have been measured experimentally, in dogs, using closed and open chest massage. No significant difference in these values was revealed between the two methods, although blood flow was less than normal (Reddings and Cozine, 196r). Precordial thumping was used to treat asystole in StokesAdams attacks (McLachlan, 1960) but its value in cardiac arrest is less certain.

Although ventricular fibrillation was known to Vesalius (Farrington, I93I), it was not until the turn of the century that methods were devised to abolish it (Prevost and Battelli, I899). These workers used an alternating current, applied directly to the heart, and were successful. More recently, closed-chest electrical defibrillation has been achieved (Zoll, Linenthal, Gibson, Paul and Norman, 1956; Kouwenhoven, Milnor, Knickerbocker and Chestnut, 1957).

Measurements of tidal volume have been made in intubated patients with cardiac arrest, during closed-chest massage. These revealed that, by this means alone, no significant ventilation was produced (Safar, Brown and Holtey, 1962). These workers point out the importance of intubation and positive pressure ventilation in cardiac resuscitation. The ventilation is given after every fourth stroke of external massage, while the chest is motionless (Safar, 196r). The advantages of expired-air respiration methods in the emergency resuscitation of patients was recognized only recently. It has been shown by careful radiological techniques that hyperextension of the neck procures the best possible airway for this purpose (Green, Elam and Dobkin, r96r).

Since Crile and Walley stressed the importance of establishing the venous return, there have been reported instances of successful resuscitation by limb elevation alone (Woodward, I960; Fowler, 1952; Stephenson, 1958). A method consisting of intermittent flexion and extension of the body, has been described and used with success in treating cardiac arrest, occurring during anæsthesia in children (Rainer and Bullough, 1957). It has been pointed out that cardiac massage without intravenous fluids may aggravate splanchnic pooling and worsen the situation (Sealy, r96r). In this connection it is interesting to note that intra-arterial drip therapy is, at present, the method of choice in the U.S.S.R., in resuscitating adults, although closed-chest massage is preferred in children (Hosler, 196r).

Since Ringer (1883-4) made his original observations on the effect of calcium and potassium ions on the contractility of the heart, several drugs have been used in the treatment of cardiac arrest:
3 to $4 \mathrm{ml}$. of a $10 \%$ solution of calcium chloride is used to increase the tone and contractility of the heart muscle (Kay and Blalock, I95I) and potassium citrate or chloride to procure asystole in an effort to abolish ventricular fibrillation. Although adrenaline has been suggested by American workers, an awareness of the danger of provoking ventricular fibrillation has limited its use in this country.

Cardiac arrest may be thought of as a sudden loss of cardiac output due to myocardial standstill, or ventricular fibrillation (Jude and others, 1961). It is important to realize that resuscitation implies the restoration of heart action, ventilation and the circulating blood volume. To undervalue any one of these factors, is to overlook the fact that the circulation and respiration are but two aspects of the same task, the provision of oxygen to tissues (Graham, I96I). Cardiac resuscitation may be divided chronologically into the following stages: detection of cardiac arrest, the restoration and maintenance of vital functions, and the after-care of the resuscitated patient.

In an emergency with a critical revival time of about $3 \frac{1}{2}$ minutes, it is reasonable to suppose that early detection is of vital importance, yet up to now, it has received little attention. This is all the more difficult to understand, as potential cases of cardiac arrest are recognized beforehand; in, for example, patients following cardiac surgery, or those who have already sustained one period of cardiac arrest. Although a method of detecting these cases has been described (Trotman, 1960) it has not been widely adopted in this country.

The immediate perfusion of vital centres to ensure their viability is the prime aim of cardiac resuscitation. If this cannot be achieved within the critical period of $3 \frac{1}{2}$ minutes, subsequent more specialized procedures lose their point. We believe that two operators, working at the bedside, can maintain an adequate circulation and respiration for a limited period of time, until more specialized aid arrives. For this reason the procedure adopted during the period of initial resuscitation needs to be understood and rehearsed, to the smallest detail. Having restored vital functions, the continued maintenance of this state is essential. Three main measures are required: intubation with positive pressure ventilation, external cardiac massage and the provision of an adequate venous return. The former procedure carries no special problems, if it is ensured that the chest is fully ventilated during regular pauses in external cardiac massage. It is thought that at least I 1 . of oxygen per minute is required for efficient ventilation under these circumstances. With regard to external cardiac massage however, we have encountered many 
difficulties in its use. We find it to be an exhausting procedure calling for several changes of operator, and wasteful of the energies of specialized personnel. Furthermore, if the pulse volume is taken as an index of perfusion, it varies, depending on the enthusiasm of the operator, and indeed, from stroke to stroke. It was to meet these difficulties that a machine was designed by one of us (A.W.W.). Used in its present form it enables closed-chest massage to be given for prolonged periods of time by an unskilled person (Don Michael, Taylor and Warltier, 1962). Having attempted to re-establish perfusion to vital centres, the next task is to ascertain the basic cardiac status. This can be done by an electrocardiogram, and cases fall into two categories; asystole and ventricular fibrillation. In patients with cardiac asystole, where adequate closed-chest massage and ventilation have failed to restore spontaneous heart action, 3 to $4 \mathrm{ml}$. of a $10 \%$ solution of calcium chloride may be given, intravenously. Where ventricular fibrillation is present, we have been disappointed by the results of the use of drugs, and feel that electrical defibrillation is the method of choice. Up to now, this has involved transferring the patient to the theatre for thoracotomy. We have found this to be unsatisfactory, as it is virtually impossible to maintain effective resuscitation during transport. The alternative is opening the chest wherever the cardiac arrest occurs and the technical difficulties, delay and hazards of sepsis from such a procedure are too well recognized. There would seem to be a strong case at present for using an external defibrillator, although the disadvantages and difficulties experienced with the instrument need to be considered.

The after-care of the resuscitated patient raises several issues. Neurological sequelæ have been reported, some of which have cleared up spontaneously. In the treatment of the unconscious patient, hypertonic fluids have been used intravenously, but they are not without risk (Julian, 196r). Sustained hypotension calls for an intravenous drip of a pressor agent such as metarminol (Aramine). In the management of prolonged unconsciousness, profound hypothermia with only adequate hydration to maintain basal renal function, has been advocated (Sealy, 1961). In all cases, a close watch must be maintained on the patient to detect cardiac re-arrest.

The decision as to whom to resuscitate is a difficult one and needs to be taken individually. We feel that it is justifiable to resuscitate cases of cardiac arrest, but unethical to officiously interfere with the natural process of death, where it is possible to make this distinction. The problem of how long to persevere in applying resuscitation procedures does not admit of a ready solution either, and one has to be guided by the response to treatment, and the nature of the underlying disturbance. We feel that closed-chest resuscitation should always be used as the method of choicê outside the operating theatre, and that even therg it should be the first line of treatment. The dangers of thoracotomy and direct massage ais known: septic mediastinitis, cardiac bruising and rupture, while those of closed-chest massage anges less frequent and mild. Fractured ribs are small price to pay, and more serious complications such as hepatic laceration, hæmopercardium and hæmothorax are becoming less common as ex perience is gained with the technique (Barringeg 1961). There is also evidence that these complices tions do not intrinsically belong to the methow Furthermore, the use of the machine, whic ensures accurate placing of the thrust and calibrated minimum force to obtain a pulseg minimizes the mechanical hazards of closed-chesf massage.

\section{The Machine for External Cardiac Massage} (Designed by A. W. Warltier)

This machine (Figs. I and 2) is basically $\frac{\mathbb{Q}}{4}$ plunger (A) operated by a lever (E) supportedo엉 a rigid framework that fits over a bed, couct stretcher, etc. The wheels, that are used when moving it into position, turn up, so that it stantos on a firm base when in use. A board (B) is sliu under the patient and this is located by pegs ( on the side-supports of the machine when it wheeled over the bed. These side-supports are adjustable vertically to match the height of an⿳亠口冋. bed, stretcher, couch, trolley, etc. Large wheep nuts (D) clamp the side supports to the frame work. The plunger, faced with special firm rubber, is carried on a rod that is threaded with $\frac{9}{9}$ rapidly adjustable thread (F). This is screwegd down to touch the patient's chest and secured with. the locknut $(\mathrm{G})$. A second plunger is clipped to the framework of the machine. This has a longer rod for smaller patients including children and the diameter of the plunger is smaller in keeping with the chest size of these patients. An adjustabo threaded stop $(\mathrm{H})$ is fitted below the operating handle, to limit the displacement of the plungegs A calibrated scale is fitted to show the distance the sternum is depressed. When the adjustment 19 correct (i.e. a satisfactory femoral or carotid pulse is obtained), the stop is locked with another locknut (K).

This machine enables an operator to carry oụt external cardiac massage with much less effort. maintaining a steady pulse pressure. The change over from manual massage to the machine tak about 20 to 30 seconds. 


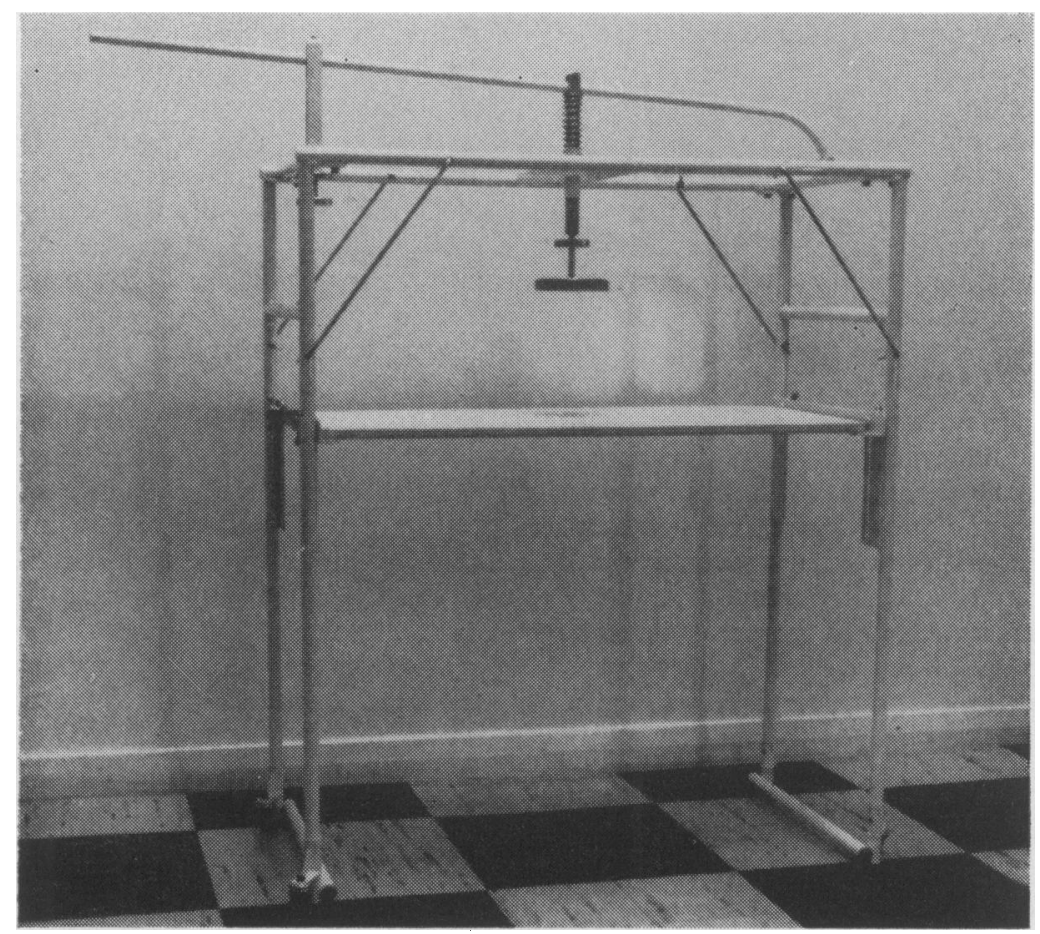

Fig. I.

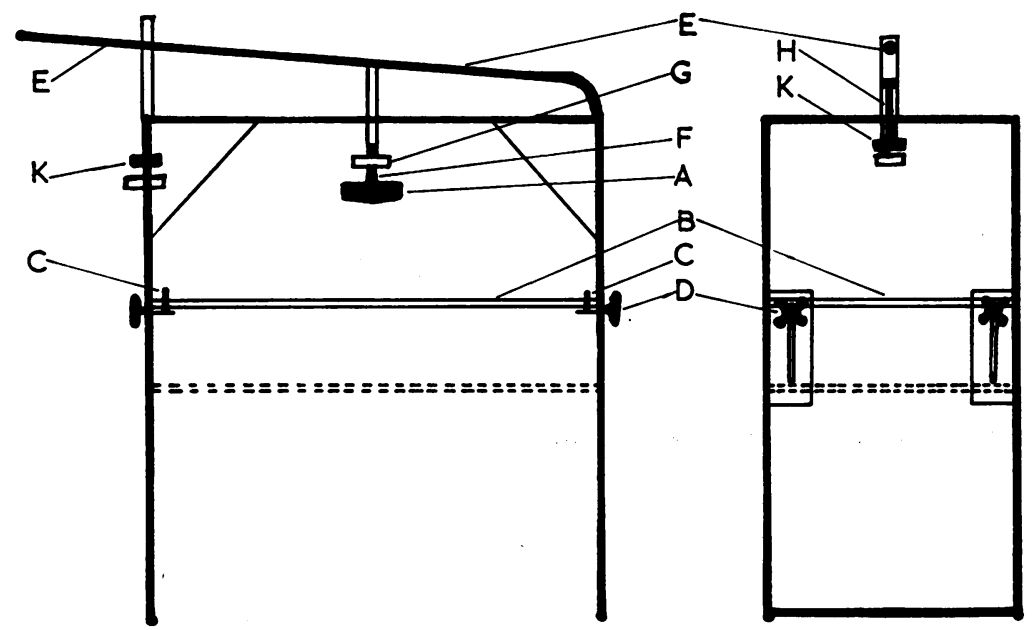

Fig. 2.

The machine is wheeled over the bed on which the patient is lying. The board has already been slid under the chest while manual massage is being carried out. The wheels are turned up and the side-supports positioned under the board so that the locating pegs engage in the slots. The sidesupports are raised, pressing firmly under the board, and are clamped in position with the wheelnuts. The plunger is screwed down to touch the chest over the lower third of the sternum and locked. The operating lever is depressed to give one inch displacement of the sternum (in a normal sized adult) and an observer says whether a pulse is felt (we usually use the femoral). The length of successive strokes is increased, if necessary, by lowering the adjustment stop until an adequate pulse is felt. The stop is then secured by the locknut.

Massage can now be continued by depressing the lever on to the stop at a rate of 60 per minute. 
This task may be allocated to an unskilled person. (In one of our successful cases, two porters continued massage for 30 minutes.)

Since external cardiac massage compresses the chest as a whole, some of the blood in the great veins is possibly forced away from the right side of the heart (Weale and Rothwell-Jackson, 1962), and this must return before the next stroke can be effective. We find that short, sharp thrusts on the operating lever, allowing for a longer filling phase, give the most satisfactory femoral pulse.

While the machine has been positioned and adjusted, artificial respiration, preferably with a cuffed endotracheal tube, has been in progress. An ECG recording and subsequent treatment can then be instituted with unhurried deliberation.

The framework of the machine has been designed to allow easy access to the patient and it does not obstruct ECG recordings or any other procedure. It is easily moved and adjusted by one person. For long distance transportation, it can be unbolted and packed flat. By keeping the design simple the cost has been kept to a minimum so that it is available to units without special funds.

\section{Clinical Experience}

Cardiac resuscitation methods have been in use in this hospital for the past two years. This period may be divided into two phases; the first 18 months, in which independent attempts were made, with no adequate records, and the past six months during which the whole hospital has been organized to deal with these cases, on a team basis. It is estimated that about 30 or more attempts were made, altogether, but reasonably accurate data are available in the last 18 cases. The information about these is summarized in Table 1 .

As can be seen from this table, ten out of the 18 cases had ventricular fibrillation and in eight of these, the underlying cause was ischæmic heart disease. The age range of the patients was from 27 to 77 years, the majority being between 50 and 70. Most of the electrocardiographic tracings were taken approximately five to ten minutes after cardiac arrest. There is no instance of a tracing taken at the actual time of arrest. In four cases $(3,13,14,15)$, the ECG after arrest was normal; three of these occurred during induction of anæsthesia in persons with no known cardiac disease. An adequate response to external cardiac massage, i.e. a good-volume femoral pulse, was obtained in all cases except in case No. 6. The poor response in this case was probably due to severe aortic stenosis. It is interesting to note that a good response was obtained in case 17 , despite post-mortem evidence of occluding thromboses-in-situ of the main pulmonary arteries, in a patient with an atrial septal defect (Don Michael,
1962). In the majority of cases, following ( period of effective cardiac massage, dilated pupi returned to normal and spontaneous respiratio 9 commenced. The length of time from cardiac arrest to initiation of treatment was probably unde $\overrightarrow{\overline{5}}$ three and a half minutes, except in case ro. If many of the cases, the exact duration of resuscic tative procedures had not been noted, but the longest period of resuscitation, followed by rea covery, was about four hours (case No. 16).

External cardiac massage was used as the pro cedure of choice, thoracotomy being necessary whe $\vec{\Phi}$ defibrillation was indicated, since only an internat defibrillator was available.

The drugs used were calcium gluconate, prog caine amide, hydrocortisone, molar sodium lactate and adrenaline. In general, they were rathew disappointing in their results and we feel thate apart from the use of the calcium gluconate in the treatment of asystole, the other drugs were too unpredictable in their results to be of values Despite the view that adrenaline initiates an perpetuates ventricular fibrillation, we have found it of use in selected cases. We have observe $\Phi$ electrocardiographically and by direct inspectiog of the heart, that adrenaline produces large amplitude fibrillation waves in already established. ventricular fibrillation (Fig. 3), and in one casse ventricular tachycardia with a recordable blond pressure resulted (case No. I). We feel that drug has a possible use in ventricular fibrillation of small amplitude, prior to defibrillation.

Out of the overall i 8 cases, ten reverted to sinus rhythm for a variable period of time. Of the te cases with ventricular fibrillation, reversion was possible only in five. No neurological sequal: were observed in the cases which recovered. $I \bar{I}$ this context, we feel that although there is theoretical risk of cardiac resuscitation resultin in recovery with residual severe dementia, this not clinically predictable, nor is it a likely even where the criteria for resuscitation aforementione are observed.

\section{Illustrative Case History}

W.W., a 64-year-old male patient was admitted for investigation of a recent increase in dyspnca. He had. suffered from chronic bronchitis for 20 years and from hypertension and ischæmic heart disease, since r $95 \%$ Clinical examination revealed a slightly breathles\$ patient. In the chest there were signs compatible wit collapse of the right upper lobe and a slight generalized wheeze. The blood pressure was $170 / 100 \mathrm{~mm}$. Hg The chest X-ray confirmed collapse of the right upper lobe and a provisional clinical diagnosis of carcinoma of the right upper lobe bronchus was made.

On 22.1.62 bronchoscopy, under a general anæsthetic, revealed a mass obstructing the R.U.L. bronchus. At biopsy was taken and subsequent bleeding controlle $\bar{\phi}$ with isoprenaline. Soon after, cardiac arrest occurred Cardiac massage was given immediately, by the externff 
TABLE 1

\begin{tabular}{|c|c|c|c|c|c|c|c|c|c|c|}
\hline \multirow[b]{2}{*}{$\begin{array}{c}\text { Case } \\
\text { No. }\end{array}$} & \multirow[b]{2}{*}{ Sex } & \multirow[b]{2}{*}{ Age } & \multirow[b]{2}{*}{ Previous History } & \multirow[b]{2}{*}{ E.C.G. } & \multirow[b]{2}{*}{$\begin{array}{l}\text { Length } \\
\text { of Ext. } \\
\text { Massage }\end{array}$} & \multirow[b]{2}{*}{$\begin{array}{c}\text { Defibril- } \\
\text { lation }\end{array}$} & \multirow[b]{2}{*}{ Drugs Used } & \multicolumn{2}{|c|}{ Recovery } & \multirow[b]{2}{*}{$\begin{array}{c}\text { Final } \\
\text { Assessment }\end{array}$} \\
\hline & & & & & & & & $\begin{array}{l}\text { Return } \\
\text { to Sinus } \\
\text { Rhythm }\end{array}$ & $\begin{array}{l}\text { C.N.S. } \\
\text { Recovery }\end{array}$ & \\
\hline $\mathbf{I}$ & M. & 54 & $\begin{array}{l}\text { Hypertensive } \\
\text { ischæmic heart } \\
\text { disease }\end{array}$ & V.F. & Not known & + & None & $\begin{array}{c}+20 \\
\text { minutes }\end{array}$ & None & Myocardial infarct. \\
\hline 2 & M. & 64 & $\begin{array}{l}\text { Carcinoma bronchus } \\
\text { Ischæmic heart }\end{array}$ & V.F. & Not known & 1 & None & 1 4 days & 4 days & $\begin{array}{l}\text { Cardiac arrest dur- } \\
\text { ing bronchoscopy }\end{array}$ \\
\hline 3 & F. & 69 & $\begin{array}{l}\text { Traumatic rupture } \\
\text { of axillary artery }\end{array}$ & Normal & 10 minutes & - & None & $\begin{array}{c}+ \text { Per- } \\
\text { manent }\end{array}$ & $\begin{array}{l}\text { Per- } \\
\text { manent }\end{array}$ & $\begin{array}{l}\text { Cardiac arrest dur- } \\
\text { ing anæsthesia }\end{array}$ \\
\hline 4 & M. & 60 & $\begin{array}{l}\text { 10 years ischæmic } \\
\text { heart disease }\end{array}$ & V.F. & 30 minutes & + & $\begin{array}{l}\text { Ca. gluconate, } \\
\text { pronestyl, } \\
\text { adrenaline }\end{array}$ & None & None & Myocardial infarct. \\
\hline 3 & M. & 54 & $\begin{array}{l}\text { Collapsed in } \\
\text { casualty }\end{array}$ & $\begin{array}{l}\text { Bradycardia, } \\
\text { Ist degree } \\
\text { heart block }\end{array}$ & 45 minutes & - & None & None & None & Myocardial infarct. \\
\hline 6 & M. & 39 & Angina pectoris & V.F. & 35 minutes & + & Hydrocortisone & None & None & $\begin{array}{l}\text { Rheumatic aortic } \\
\text { stenosis }\end{array}$ \\
\hline 7 & M. & 65 & $\begin{array}{l}\text { Chronic bronchitic } \\
\text { Cardiac failure }\end{array}$ & $\begin{array}{l}\text { 1. Asystole } \\
\text { 2. 3rd degree } \\
\text { heart block } \\
\text { 3. Asystole }\end{array}$ & 40 minutes & - & None & None & None & Posterior infarct. \\
\hline 8 & M. & 63 & $\begin{array}{l}\text { Chronic bronchitic } \\
\text { Myocardial infarct. }\end{array}$ & V.F. & 2 hours & + & $\begin{array}{l}\text { Pronestyl, } \\
\text { hydrocortisone, } \\
\text { molar lactate, } \\
\text { ca. gluconate }\end{array}$ & +1 hour & None & Myocardial infarct. \\
\hline 9 & M. & 55 & $\begin{array}{l}\text { Ischæmic heart } \\
\text { Heart block, } \\
\text { Grade III }\end{array}$ & $\begin{array}{l}\text { 1. Asystole } \\
\text { 2. V.F. } \\
\text { 3. Asystole }\end{array}$ & I hour & + & $\begin{array}{l}\text { Ca. gluconate, } \\
\text { adrenaline, } \\
\text { molar lactate }\end{array}$ & None & None & \\
\hline 10 & M. & 47 & $\begin{array}{l}\text { Carbon monoxide } \\
\text { poisoning }\end{array}$ & Asystole & Not known & - & None & None & None & $\begin{array}{l}\text { Carbon monoxide } \\
\text { poisoning }\end{array}$ \\
\hline I I & F. & 77 & $\begin{array}{l}\text { Ischæmic heart } \\
\text { Cardiac failure }\end{array}$ & V.F. & 30 minutes & - & None & None & None & - \\
\hline 12 & M. & $5^{8}$ & $\begin{array}{l}\text { Ischæmic pain for } \\
24 \text { hours }\end{array}$ & V.F. & 20 minutes & - & None & None & None & Myocardial infarct. \\
\hline $13 \mathrm{a}$ & F. & 27 & $\begin{array}{l}\text { High serum } \mathrm{K}^{+} \\
\text {due to lower } \\
\text { nephron nephrosis }\end{array}$ & (a) Normal & Io minutes & - & None & $\begin{array}{l}+9 \\
\text { hours }\end{array}$ & 9 hours & $\begin{array}{l}\text { Cardiac arrest due } \\
\text { to hyperkalæmia }\end{array}$ \\
\hline $13 \mathrm{~b}$ & & & & $\begin{array}{l}\text { I. V. tachy- } \\
\text { cardia } \\
\text { 2. V.F. }\end{array}$ & 3 hours & - & $\begin{array}{l}\text { Ca. gluconate, } \\
\text { insulin, } \\
\text { hydrocortisone, } \\
\text { adrenaline }\end{array}$ & $\begin{array}{l}+ \text { A few } \\
\text { minutes }\end{array}$ & None & \\
\hline 14 & F. & 55 & $\begin{array}{l}\text { A.P. resection of } \\
\text { rectum }\end{array}$ & Normal & 10 minutes & - & None & $\begin{array}{l}+ \text { Per- } \\
\text { manent }\end{array}$ & $\begin{array}{c}\text { Per- } \\
\text { manent }\end{array}$ & $\begin{array}{l}\text { Cardiac arrest dur- } \\
\text { ing anæsthesia }\end{array}$ \\
\hline 15 & M. & 63 & Hæmorrhoidectomy & Normal & ro minutes & - & None & $\begin{array}{c}+ \text { Per- } \\
\text { manent }\end{array}$ & $\begin{array}{c}\text { Per- } \\
\text { manent }\end{array}$ & $\begin{array}{l}\text { Cardiac arrest dur- } \\
\text { ing anæsthesia }\end{array}$ \\
\hline 16 & M. & 49 & Posterior infarct. & V.F. & 4 hours & $t$ & $\begin{array}{l}\text { Molar lactate, } \\
\text { pronestyl, } \\
\text { hydrocortisone }\end{array}$ & $\begin{array}{c}+4 \\
\text { hours }\end{array}$ & 4 hours & Myocardial infarct. \\
\hline 17 & F. & 51 & $\begin{array}{l}\text { A.S.D. } \\
\text { Pulmonary } \\
\text { hypertension }\end{array}$ & V.F. & I $\frac{1}{2}$ hours & + & Adrenaline & None & None & Pulmonary embolus \\
\hline 18 & F. & 60 & $\begin{array}{l}\text { Mitral stenosis } \\
\text { Rheumatoid arthritis }\end{array}$ & Asystole & 2 hours & - & $\begin{array}{l}\text { Adrenaline, } \\
\text { pronestyl, } \\
\text { ca. gluconate }\end{array}$ & $\begin{array}{l}\text { + Inter- } \\
\text { mittently }\end{array}$ & None & $\begin{array}{l}\text { Mitral and aortic } \\
\text { stenosis } \\
\text { Pleural and peri- } \\
\text { cardial effusions }\end{array}$ \\
\hline
\end{tabular}

route, and a satisfactory femoral pulse obtained. An endotracheal tube was passed and the patient kept well ventilated. External massage was continued using the machine, which was hand-operated by a porter after adjustment. The electrocardiogram showed ventricular fibrillation and it was decided to perform thoracotomy and defibrillation. The circulation and respiration were thus maintained for approximately 20 minutes, before surgery was performed. Defibrillation was effective at the fourth attempt (Fig. 4). After a short period of further massage by the internal route, the heart restarted in sinus rhythm at a rate of $150 / \mathrm{min}$., the blood pressure was $180 / 110$ and spontaneous respiration commenced. The pericardium was partially repaired and the chest wall closed with an apical drain in-situ. Consciousness gradually returned after about two hours but the patient was, at first, restless and confused. Therefore magnesium sulphate was given rectally. Approximately six hours after cardiac arrest, he was fully conscious and co-operative with no apparent neurological sequelæ. His subsequent course was as follows: 


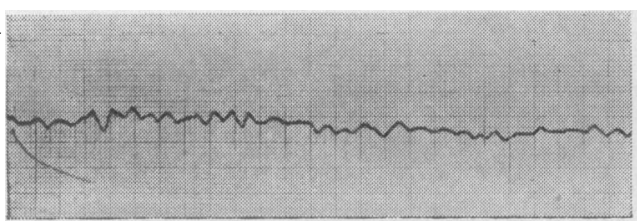

Fig. 3.-(a) Ventricular fibrillation.

(b) Ventricular fibrillation with larger amplitude waves following Adrenaline.

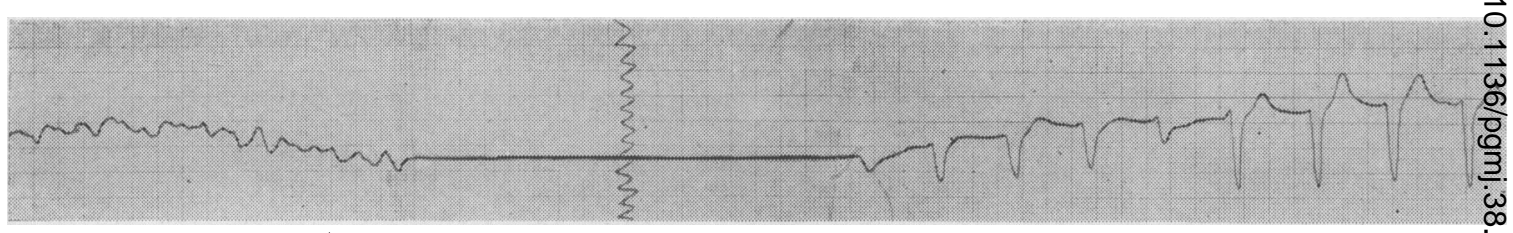

Fig. 4.-Case report. Shows ventricular fibrillation reverting to sinus rhythm following defibrillation.

23.1.62 Atrial fibrillation at $160 / \mathrm{min}$. developed with hypotension which responded to digoxin and vasopressor drugs. The left lung showed signs of expansion.

24.1.62 There was reversion to sinus rhythm and all but the lower lobe of the left lung had reexpanded.

25.1.62 He was well during the day but in the evening suddenly collapsed and died.

Post-mortem showed petechial hæmorrhages under the visceral pericardium and endocardium, also recent cardiac infarcts. The right lung showed a collapsed R.U.L. with a mass occluding the corresponding bronchus. There were two fractured ribs on the left side. No abnormalities were seen in the brain but there were secondary neoplastic deposits in the liver.

This case demonstrates some of the problems encountered in the treatment of cardiac arrest.

(I) It emphasizes the value of instituting resuscitative procedures, without delay; in all our successful cases, medical staff were present at the time of arrest. Where specialized aid was summoned or patients brought into the Casualty Department, before treatment was begun, the results of treatment have been poor.

(2) It illustrates the value of adequate oxygenation. The cardiac arrest described occurred in the presence of an anæsthetist and there was no delay in intubation and artificial ventilation. Where this is not possible, expired-air resuscitation may be performed, prior to external cardiac massage, as there is no virtue in circulating de-oxygenated blood.

(3) External cardiac massage and adequate ventilation are capable of maintaining the viability of vital centres, until the basic cardiac abnormality is corrected.
The hazards of external massage have bee $\vec{\beta}$ previously pointed out but in our experiences fractured ribs have been the only common complo cation. We have not met with hepatic, pulmonarf or cardiac laceration.

\section{Organization}

We feel that for the best chance of success in the treatment of cases of cardiac arrest an organized approach is needed and that this must embraco the whole hospital, irrespective of the ward of department in which it occurs. We furthe? believe that a set procedure must be followed ô each occasion so that everyone taking part knows exactly what has to be done, ensuring a speedy an efficient operation. During the past year, a members of the hospital staff have agreed on 9 routine that has been evolved to suit our particular. needs, taking into account that we have only the facilities of any general hospital. On this basis, adi medical staff have received instruction in the technique to be followed and the training of tho nursing staff is still taking place. Each ward and department has been equipped with the necessar minimum of apparatus. This includes a re suscitation box containing: a mouth to moutw airway, laryngoscope, endotracheal tubes, bago inflator to connect to an oxygen cylinder and supply of drugs likely to be needed. There also a board to slide under the patient which give counter-pressure during massage to obviate the displacement of the mattress. These boards ate of a shape and size so that they fit the machine that is used for external cardiac massage. Thos standard equipment is kept in a similar place 諵 each ward which is central and readily accessible 


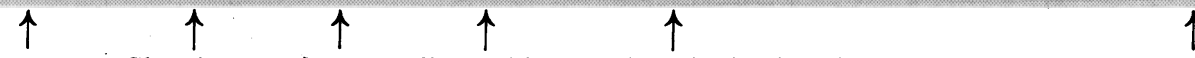

FIG. 5.- Showing an electrocardiographic complex obtained each time the chest was thumped. This corresponds with a palpable femoral pulse.

The resuscitation is carried out by a team composed of the duty medical registrar, anæsthetist, house physician and casualty officer, also the duty. surgical registrar when thoracotomy is indicated. With this combination three out of the four are almost certain to be able to leave anything they are doing, immediately. They are given an emergency call by the telephone operator, who is a vital link in the organization. From the time the alarm is given, the members of the team, the cardiac massage machine and an ECG machine can be assembled in approximately four to five minutes. It is obvious that this time interval is too long for the emergency team to be able to treat any case, unless effective action has already been initiated by the person on the spot. For this reason in 'Instructions to Nursing Staff' giving the alarm is placed well down the list, in fact, not until some form of effective resuscitation has already been started. Work is currently taking place to short-circuit several of the links in this chain of communication and give an immediate alarm to the team, automatically.

We realize the difficulty of a nurse making the diagnosis of cardiac arrest and the physical effort involved in carrying out massage manually, but the patient's only chance of survival depends on this immediate action. (The sister's report will mention those cases of terminal disease where attempts at resuscitation are not justified.) Similar observations can be made with respect to first-aid workers and lifeguards, etc., outside hospital, as for example in cases of electric shock and drowning (Middleton, 1962). We believe that it is in this field that the most dramatic results will be achieved, for these workers are dealing with a representative cross-section of the population. This is in contrast to hospital patients suffering cardiac arrest who, in the majority of cases, have some form of cardiac disease. There is little chance of success in a case of cardiac arrest transported to hospital, unless treatment has already been started. As yet, the London Ambulance Service has not recognized this form of treatment.

The place of external cardiac massage in the treatment of cardiac arrest is being more widely recognized and more first-aid units are being trained in its application. This year it has been added to the syllabus of training of The British Red Cross and St. John's Ambulance Brigade (Emergency Resuscitation, 1962).

Instructions to Nursing Staff, Emergency Team and Telephone Operator take the following form:

\section{ST. STEPHEN'S HOSPITAL \\ CARDIAC ARREST}

\section{INSTRUCTIONS TO NURSING STAFF}

In the instance when a patient suddenly collapses, the following routine should be strictly adhered to:

I. Feel the pulse to confirm that cardiac arrest has taken place.

2. Lie the patient flat on the bed or floor, depending on position when arrest occurs.

3. Call for assistance to a member of the staff or a patient.

4. Extend the patient's jaw, block the nose and perform mouth to mouth assisted respiration 3-4 times.

5. Immediately after perform external cardiac massage.

Meanwhile the assistant(s):

I. Brings up bed-board and 'resuscitation box'.

2. Slides bed-board under patient's chest.

3. Feels for the femoral pulse at each stroke, thereby guiding the operator.

4. Performs mouth to mouth respiration after every fourth stroke of external massage.

5. Gets to the telephone and gives the alarm. State 'There is an emergency on Ward -'.

6. Brings up an oxygen cylinder and clears space round the bed.

If more than one assistant is available, the work can be divided, e.g. One gives the alarm while another brings up equipment and assists with resuscitation.

The resuscitation box will be kept on the night nurse's table.

The record of treatment takes the form of an eventtime chart where necessary details of the event are given separately, e.g. a drug is given at a certain time and a mark is accordingly made on the chart, the table below giving the details of drugs and dosage. This form has been evolved to give as much information as we may want for review later, since we have found that the summaries written after the event, since we first began, leave out what we now believe to be important details.

There are, as yet, many technical and academic 


\section{ST. STEPHEN'S HOSPITAL}

\section{CARDIAC ARREST}

\section{INSTRUCTIONS TO EMERGENCY TEAM}

The duty team, consisting of medical registrar, anzesthetist, duty H. P. and casualty officer, will be called in all cases of cardiac arrest.

Medical Registrar-Confirm arrest and:

I. Decide whether further resuscitation is warranted.

2. Check bed-board is in position and perform external massage.

3. Instruct staff to maintain assisted respiration using 'bag-squeeze' apparatus until anzsthetist arrives.

4. Position and adjust the 'Warltier' machine.

5. Read E.C.G. and decide on subsequent treatment, calling duty surgeon if thoracotomy is indicated.

Anasthetist

Intubate patient and perform assisted respiration. House Physician

I. Bring up E.C.G. machine en route to ward.

2. Check on the efficacy of external cardiac massage.

3. Get E.C.G. tracing.

External massage will be continued until the pericardium is opened, thereafter internal massage is performed.

\section{ST. STEPHEN'S HOSPITAL}

\section{CARDIAC ARREST}

INSTRUCTIONS TO TELEPHONE OPERATOR

On receiving the message:

'THERE IS AN EMERGENCY ON WARD -':

I. Call the duty team URGENTLY.

2. Arrange for porter to take the 'Warltier' machine from casualty to the ward.

The duty team consists of: Medical Registrar, Anzesthetist, House Physician and Casualty Officer.

problems to be solved in cardiac resuscitation. These include measurement of the cardiac output, blood gas analysis, demonstration of the direction and efficiency of the circulation and estimation of the force required to achieve cardiac compression.
The technique of cardiac pacing using rhythmiñ blows to the chest wall has been described (McLachlan, 1960). We found this technique to̊ be successful in several of our cases of asystole ${ }^{c}$. The electrocardiographic response to such an $\overrightarrow{\vec{F}^{2}}$ attempt is shown (Fig. 5). However, the value of precardial thumping in resuscitation has yet to be fully assessed. It has the advantage of being freesfrom the complications met with in using cardiaco massage (Feraru, 1962). We have used closed $\cong$ chest massage in a patient with 'irreversible है shock of central origin. Following two hours of external massage, a normal blood pressure wasobtained. However, we feel that all that can be్లు claimed, in this instance, is that external massage can be used in a live patient without injuriouș effects.

\section{Summary}

I. The history and rationale of cardiac resusci tation have been discussed.

2. The methods, administrative details and techniques to deal with this emergency, in a generat hospital, have been outlined.

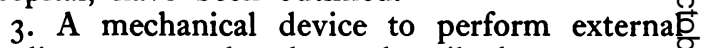
cardiac massage has been described.

4. The results of attempted resuscitation in $88_{0}$ cases were as follows:-

Ten reverted to sinus rhythm.

Three recovered consciousness for several houts or days, but died subsequently.

Three completely recovered and were dis charged from hospital.

No serious side-effects were experienced and no neurological sequelæ seen.

5. The academic aspects, limitations and future possible uses of closed-chest massage have been considered.

Our thanks are due to the encouragement and support of the physicians, surgeons and anæsthetists of this hospital whose co-operation was essential to our task also to Mr. W. H. W. Jayne who performed several of the thoracotomies.

The machine described above has been patented (Brit. Prov. Pat. No. 02409-62) and is being manus factured by Messrs. Silentbloc of Crawley, Sussex, toD whom we are indebted for the photograph.

\section{REFERENCES}

Barringer, J. R. ( 1961): 'External Cardiac Massage', New Engl. Y. Med., 265, 62.

Clendening, L. (1942): 'Source Book of Medical History'. New York: Paul B. Hoeber.

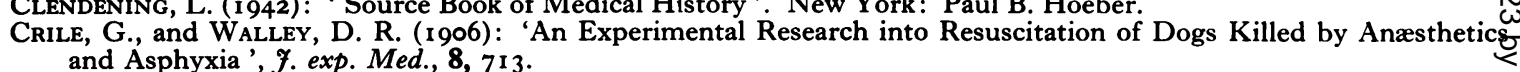

Don Michael, T. A. (1962): 'Thrombosis in situ of the Main Pulmonary Artery', Postgrad. med. F., 38, 301.

- - TAYlor, D. J. E., and Warltier, A. W. (1962), 'External Cardiac Massage', Lancet, r, 384.

'Emergency Resuscitation': Provisional Supplement No. I to First Aid. London: H.M.S.O.

FARrington, B. (1931): 'De Fabrica' of Vesalius Chap. entitled: 'Some Observations on the Dissection of Livingo Animals' (Bover vii., Chap. 19), Trans. Roy. Soc., South Africa, 20, 1.

Feraku, F. (1962): 'Restarting the Arrested Heart', F. Amer. med. Ass., r8o, 628.

Fowler, A. W. (1952): 'Cardiac Arrest during Operation', Brit. med. f., ii, 723. 
Name

REc. No.

ST. STEPHEN'S HOSPTAL

CARDIAC ARREST RECORD

Date

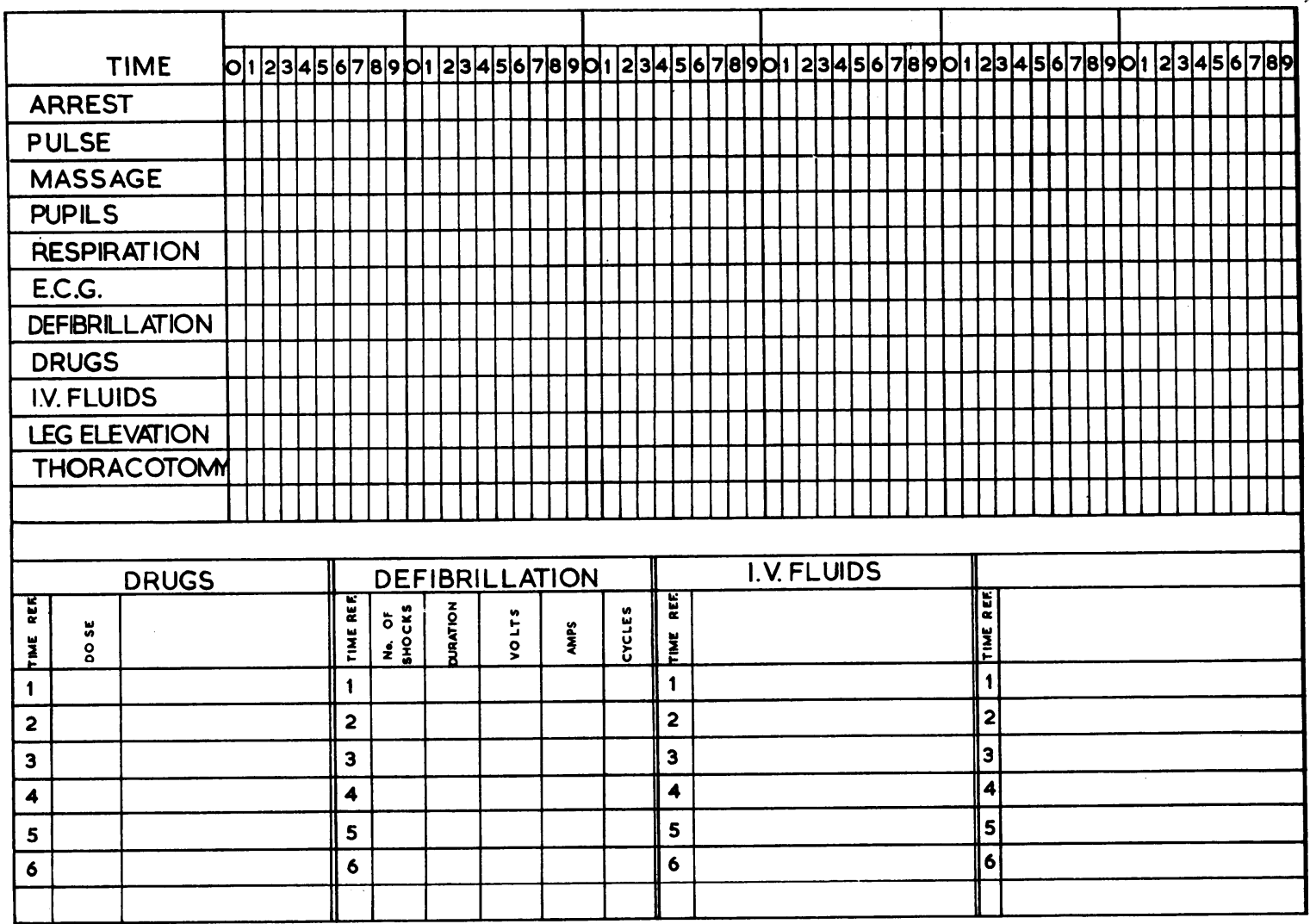

Graham, G. R. (1961): 'Physiological Aspects of Circulatory Arrest and Resuscitation', Brit. F. Ancesth., 33, 10.

GreEn, D. L., ElaM, J. D., and DobKin, A. B. (1961): 'Cinefluorographic Study of Hyperextension of the Neck and Upper Airway', \%. Amer. med. Ass., 176, 570.

GurewiCH, (1961): 'Aortic Pressures during Closed-chest Cardiac Massage ', Circulation, 23, 593.

HOSLER, R. M. (1961): 'Present-day Cardiac Resuscitation', Amer. F. Cardiol, 8, 297.

HunTER, J. ( 1776 ): 'Proposals for the Recovery of People Apparently Drowned ', Phil. Trans., 66, 4 I 2.

IgELSRUD, K. (I9OI): 'First Successful Case'. Original personal communication. Tromso, Norway.

JUDE, J. R., KouwENHOVEN, W. B., and KNICKERBOcKer, G. C. (1961): 'Cardiac Arrest'. Report of application of external cardiac massage on 118 patients. Y. Amer. med. Ass., 178, 1063.

Julian, D. G. (196I): 'Treatment of Cardial Arrest in Myocardial Ischæmia and Infarction ', Lancet, ii, 840.

KAY, J. H., and BLALOCK, A. (195 I): 'The Use of Calcium Chloride in the Treatment of Cardiac Arrest in Patients', Surg. Gynec. Obstet., 93, 97; Brit. Y. Anasth., 33, 10.

Kouwenhoven, W. B., Jude, J. R., and KNICKERBocker, G. C. (1960): 'Closed Chest Cardiac Massage ', J. Amer. med. Ass., 173, 1064.

-, Milnor, W. R., KNickerbocker, G. C., and Chestnut, W. R. (1957): ' Closed-chest Defibrillation of the Heart ', Surgery, 42, $55^{\circ}$.

McLachlan, E. M. (1960): 'Treatment of Cardiac Arrest by Precordial Percussion'. Report of a case. N.Z. med. Y., 59, 570 .

59, 570. MidDLETON, K. R. (1962): ' Cardiac Arrest Induced by Drowning: Attempted Resuscitation by External and Internal Cardiac Massage', Canad. med. Ass. F., 86, 374.

Nixon, P. G. (196I): 'The Arterial Pulse in Successful Closed-chest Cardiac Massage ', Lancet, ii, 844.

PREvost, J. I., and BatTelli, F. (I899): 'On Some Effects of Electrical Discharges on the Heart of Mammals', C.R. Acad. Sci. (Paris), 129, 1267.

Rainer, F. H., and BUllough, J. H. (1957): 'Respiratory and Cardiac Arrest during Anæsthesia in Children', Brit. med. $\mathcal{F}$., ii, 1024.

Redpings, J. S., and Cozine, R. A. (1961): 'A Comparison of Open and Closed Chest Cardiac Massage ', Anasthesiology, 22, 280 . 
Ringer, S. (1833-1834): 'A Further Contribution regarding the Different Constituents of the Blood on the Contraction of the heart', $\mathcal{F}$. Physiol., 4, 29.

Safar, P. (1961): 'Closed Chest Cardiac Massage', Anasth. Analg. Curr. Res., 40, 609.

Brown, T. C., and Holtey, W. J. (1962): 'Failure of Closed-chest Cardiac Massage to produce Pulmonary

Ventilation', Dis. Chest., 4I, I.

Schiff, M. (1896): Receuil des memoires Physiologiques, 3. Lausanne: Benda.

Sealy, W. C. (196I): 'Cardiac Arrest', Progr. cardiovasc. Dis., 4, 285.

Starling, E., and Lane, W. A. (1902): Report of Society of Anæsthetists, Lancet, ii, I397.

Stephenson, H. E. (1958): 'Cardiac Arrest and Resuscitation, p. 144, I89. St. Louis: C. V. Mosby.

Trotman, R. E. (1960): 'A Warning Device for use in Surgery', Lancet, ii, 471 .

Weale, F. R., and Rothwell-Jackson, R. L. (1962): 'The Efficiency of Cardiac Massage ', Lancet, i, 990.

Willius, F. A., and DrY, F. J. (1948): 'A History of the Heart and Circulation. Philadelphia: J. B. Saunders.

Woodward, W. W. (1960): 'Cardiac Arrest Treated by Elevation of the Limbs for I 5 Seconds ', Lancet, ii, I I 20 (婉e

also Lancet, 1960, i, 52). Fibrillation in Man by Externally Applied Countershock', New Engl. F. Med., 254. 727. 